\title{
Biofuels from Jatropha curcas oil - Perspectives for tropical regions
}

\author{
Klaus BECKER \\ University of Hohenheim, Institute for Animal \\ Production in the Tropics and Subtropics, \\ Fruwirthstrasse 12, 70599 Stuttgart \\ <kbecker@uni-hohenheim.de>
}

\begin{abstract}
Almost 40\% of the world's population of 6,7 billion people do not have access to affordable energy resources and drinking water of acceptable quality. But nothing is more important than the alleviation of hunger. The number of hungry people, according to the newest FAO statistics, has risen to close to one billion in 2008. Therefore, special attention needs to be given to research in food and agriculture. To this stock of global problems new challenges are added through the increase in human population of 80 million persons a year and the concomitant loss of large areas of former fertile agricultural land, mostly in the poorest countries. Jatropha curcas is the most primitive member of the large genus Euphorbiaceae. The name is derived from the Greek iatros (doctor) and trophe (food). Jatropha curcas is a perennial plant, native and widely spread throughout the tropics. It is not grazed by animals, grows readily on degraded lands, is drought and to some extent disease resistant. It is a multipurpose plant. There are two genotypes of Jatropha curcas, a toxic and a non-toxic one. The latter genotype is found in Mexico only. Well developed dry seeds from Jatropha curcas weigh between 650 $750 \mathrm{mg}$ and contain $30-35 \%$ of oil that is suitable for conversion into biodiesel of high quality by the conventional, proven processes. The kernel forms around $65 \%$ of the seeds. The de-oiled kernel meal has a crude protein content of between $58 \%$ and $60 \%$ and a favourable amino acid profile. Extracts of the toxic genotype provide chemicals with potential in medicinal, pharmaceutical and bio-pesticide application. In contrast to other fossil fuel alternatives, like biofuels from food crops such as maize, soybean, sugar cane and palm, bioenergy from Jatropha curcas grown on wasteland incurs no carbon debt and thus, offers immediate and sustained greenhouse gas advantages. Potential benefits of large scale Jatropha plantations on degraded land are expected to be: availability of $\mathrm{CO}_{2}$ neutral fuel in remote rural areas; potential availability of high protein concentrates and biofertilizer locally; wasteland reclamation for food production; carbon sequestration for emission trading; employment generation and socioeconomic development for impoverished farmers and rural labourers. Because of the wild nature of the plant, productivity reports vary considerably from less than $100 \mathrm{~kg}$ to more than $10.000 \mathrm{~kg}$ of seeds per ha. This huge variation is of importance from a breeder's point of view for future selection and breeding programmes. Such programmes coupled with the development of agronomical practices, are essential prerequisites for economic exploitation to give Jatropha curcas a bright future.
\end{abstract}

Key words: biofuel, Jatropha curcas, hunger

\section{Introduction}

Close to $40 \%$ of the world's population of 7 billion people will not have access to affordable energy resources and portable water in the distant future.

Concomitantly, the number of hungry people has risen to close to one billion in 2008, according to the recent FAO statistics. To this stock of global problems new challenges are added through the increase in human population of 80-100 million annually and the concomitant loss of large areas of former fertile crop land, largely in the poorest countries.

Global petroleum growth has been quantified by the US-Energy Information Administration (EIA) [1] at 1.7 million barrels $d^{-1}$ in 2006 and is expected to increase to 1.8 million barrels $\mathrm{d}^{-1}$ in 2007 and further in the distant future ahead.
Political $\mathrm{CO}_{2}$ reduction targets in the EU have been a main driver for enhanced biofuel production. This has led to the conversion of huge areas of intact environments in hot regions to produce renewable biofuels.

Jatropha curcas, native to Central America, is a very hardy plant that grows on degraded agricultural lands or even in the desert sand of Upper Egypt. It doesn't have to compete with food crops for arable land and incurs little or no carbon debt thus offering immediate and sustained greenhouse gas advantages.

Globally, there are huge areas of wasteland available for planting Jatropha.

\section{The Jatropha plant}

The plant is reported to be approximately 70 million years old. In 1737 Karl von Linne first described and in 1753 classified Jatropha curcas. It is a member of the large Euphorbiaceae family and consists of between 165175 species.

The genus name Jatropha is derived from the Greek iatros (doctor) and trophe (food). There are two genotypes of Jatropha curcas, a toxic and a non-toxic, edible one. To the best of our knowledge the non-toxic genotype is found in Mexico only. Jatropha curcas is a shrub or a small to medium sized tree. Solitary trees grow large and can reach heights of more than $12 \mathrm{~m}$ in Paraguay. On the Cap Verde Islands trees as old as 120 years show trunk diameters close to $100-120 \mathrm{~cm}$.

It is a perennial C-3 plant, native and widely spread throughout pan tropical countries. Because of its toxic nature it is not grazed by animals and grows readily in poor stony soils. 
In fact, huge areas of former cropland are lost every year and are available for planting Jatropha curcas. A way to eventually reclaim that land again for crop production through Jatropha cultivation is not an illusion but could soon become a reality.

The plant is diploid with $2 \mathrm{n}=22$ chromosomes [2].

Standard quantitative genetic methods have not been applied to the pan tropical wild genotypes of Jatropha curcas. Only in the last couple of years first selection and breeding activities have been initiated.

The cultivation of Jatropha was of economic importance in Cape Verde and Madagascar. Export quantities of the seeds to Lisbon, Portugal is reported to have reached almost 6,000 tones in 1900 and still 4,500 tones in 1955. Trade with Jatropha seeds between Cap Verde and Portugal ended in 1970 [3, 4]. A second centre for Jatropha was on the island of Madagascar whose total harvest was exported to Marseille, France, from which the famous soap Savon de Marseille was produced. It has been reported that Jatropha curcas has an excellent adaption capacity to a huge range of soil conditions. Equally, Jatropha appears well adapted to conditions of low and very low soil fertility. Mineral deficiency symptoms are rarely observed, due to the fact that root excudates have the potential to solubilize immobile mineral complexes.

Temperature plays a central role in the Jatropha cultivation. The preferred range of average temperature lies between $25^{\circ} \mathrm{C}$ and over $30{ }^{\circ} \mathrm{C}$ depending on water availability. Jatropha is a typical tropical plant and doesn't tolerate frost and shows sensitivity to temperatures below $15^{\circ} \mathrm{C}$ by shedding its leaves and falling into a dormancy state until temperatures recover. Water deficiency leads to the same effect. Most often a combination of both of these environmental factors terminates photosynthetic activity.

The drought tolerance and adaption capacity to long, severe dry periods are well developed. On the other hand, Jatropha tolerates humid conditions equally well, showing good growth with high, well distributed rainfall.

Grown in the wild, Jatropha seems to be quite disease resistant. Planted on large areas in monocultures, this natural resistance weakens and plant protection measures are required.

The monoecious plant (i.e. unisexual reproductive units of both sexes appear on the same plant) is pollinated by insects. Jatropha is selfcompatible [5], but cross pollination is supported by a time gap between anthesis of male and female flowers [6].

Jatropha can be propagated as cuttings or with seeds. Plants propagated vegetatively do not usually form tap roots [7]. This might be a disadvantage for plants established on unfertile wasteland, as a strong tap root system facilitates effective water and mineral acquisition and use. To support a better rooting system of the cuttings they should be cut flat and not diagonal, otherwise roots only develop around the tip of the cut and not all the way around the stem. The cuttings should be lignified, $30 \mathrm{~cm}$ long and should have a diameter of $3 \mathrm{~cm}$.

\section{The multifunctional uses of the plant}

Jatropha is a multipurpose plant. Although oil production to replace fossil fuel is very often the main reason for planting this crop, the plant has other important roles, such as 1) land reclamation and additional agro ecological advantages; 2) erosion control and as shelter/support for other plants; 3) provision of protein rich seed meal after detoxification as feed for all farm animals including fish and shrimps; 4) provision of chemicals (phorbol ester) with potential in medicine, pharmaceutical and biopesticide applications (e.g. the toxic substance phorbol ester present in the oil in high concentration kills the vector snail of schistosomiasis - the second most serious human disease after malaria in the tropics - at an extremely low concentration and without harming fish in the same water body; 5) carbon dioxide emission impact (GHG reduction); 6) contribution to human welfare and the economy in particular.

The re-greening of degraded land through the cultivation of Jatropha is environmentally of vital importance. Approximately 500 million ha of land are already degraded in Africa alone. Annually we are loosing almost 10 million ha worldwide. The production of nonedible oils on these soils contributes to the agricultural and household supply in lesser developed countries. Surplus production can be sold on national or international markets for a fair price. Positive feeding results with detoxified Jatropha meal have been achieved with cold and warm water fish and salt water shrimps [8-14].

The concomitent production of renewable protein resources from energy plants with a high physiological quality is of utmost importance for small farmers in the tropics. Protein deficiency, especially in infants and small children is a serious problem. It is mainly due to the low production of animal protein because of the lack of high protein feed to achieve an acceptable performance. Detoxified Jatropha meal always showed a better performance in all feeding experiments with fish than soy meal. The protein content of Jatropha meal is about $60 \%$, $15 \%$ higher than in soy meal.
The plant's toxicity is concurrently a comparative advantage in critical environments because animals do not eat it. We have developed efficient extraction methods to remove the phorbol esters from the oil. The use of these esters is still in the early stages for many potential applications. Well established is already the extremely high potency to fight the vector snail of schistosomiasis.

Other applications are being discussed for organic agriculture, pest management and the veterinary sector.

The undamped request for fossil fuels leads to a substantial increase of $\mathrm{CO}_{2}$ emissions. The production of energy plants on farmland, former pastures or even cleared rainforest must be refrained because it will take many years before the negative $\mathrm{CO}_{2}$ balance is compensated, much less that it leads to a real economic effect. On the other hand, Jatropha grows on degraded soils (eroded/waste land) and does not accelerate carbon dioxide emission through change of land use for bioenergy production. Through its suitability for wasteland recultivation Jatropha curcas provides two mechanisms for GHG abatement: substitution of fossil fuel and $\mathrm{CO}_{2}$ sequestration through increasing carbon stocks above and below ground. Here the Clean Development Mechanism (CDM) applies. Those emission reductions in the lesser developed countries may be more cost effective than in an industrialized country. This opens up a good opportunity for developing countries to generate income next to achieving energy autharcy.

\section{Important co-products}

Figure 1 shows the morphological fractions, and their multiple uses. In figure 2, the Jatropha fruit is divided up as follows: Calculated on a basis of $1000 \mathrm{~kg}$ fruits, $350 \mathrm{~kg}$ of fruit husk and $650 \mathrm{~kg}$ of seeds are accrued. The proportion of the husk can be assumed at an average of $35 \%$ which results in about $230 \mathrm{~kg}$ of seed husk and $420 \mathrm{~kg}$ of kernels. The kernels are rich in oil and can contain anywhere from almost $50 \%$ to more that $60 \%$ oil.

The most important co-product is the kernel meal with about $180 \mathrm{~kg}$ per ton of dry fruits, or $270 \mathrm{~kg}$ of high value protein concentrate (kernel meal) from 1 ton of Jatropha seeds.

The husk (dried fruit encapsulate) of Jatropha also has a high energy content of around $16 \mathrm{MJ} \mathrm{kg} \mathrm{[15]} \mathrm{and} \mathrm{could} \mathrm{be} \mathrm{used} \mathrm{as} \mathrm{a} \mathrm{soil}$ amendment or for generating energy through burning. The seed shell is extremely lignin rich (45-51\%) and thus higher in its energy content $(\sim 19.5 \mathrm{M})$ ) than the fruit husk. Because of the intensive lignification of both these materials, their use for biogas fermentation is not a good option. 


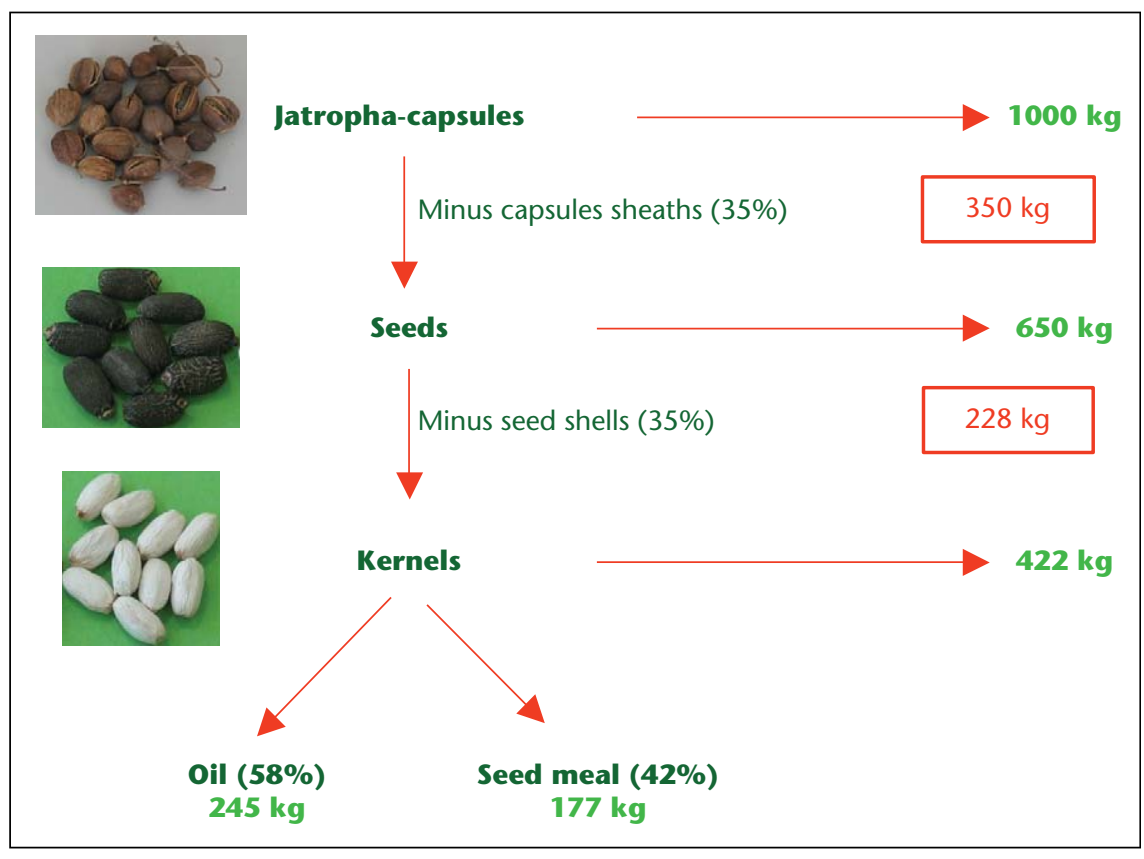

Figure 1. Jatropha curcas fractions.

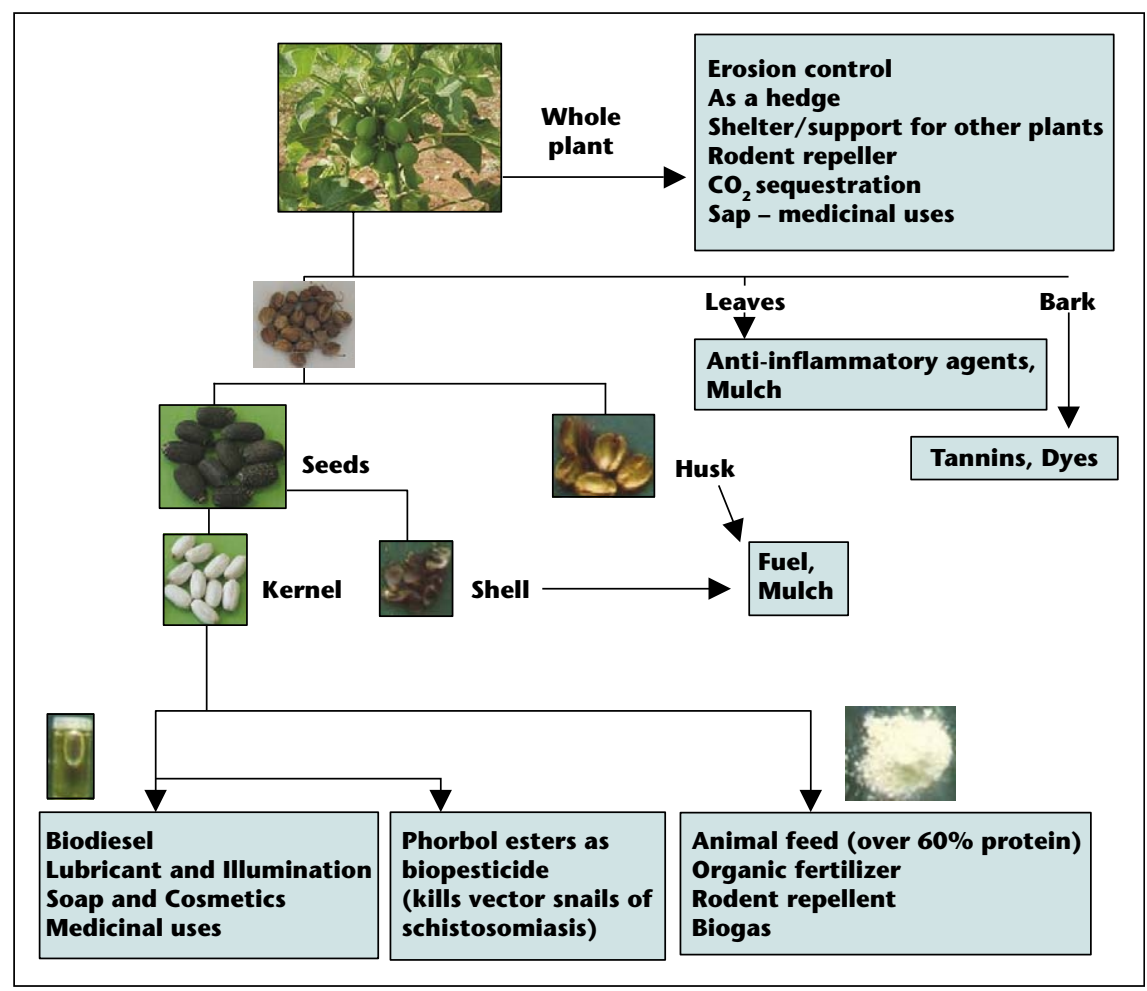

Figure 2. Jatropha curcas - multiple uses of the plant.

\section{Potential yield of Jatropha curcas plantations}

It has to be stated clearly at this point that the plant has no history of selection and breeding as we know it from other agricultural plants.
Maize, for instance, has been bred for almost 100 years now, potatoes for about 80 and plants can be increased considerably through selection and breeding. These activities are still in infancy. Some institutions have initiated canola for the last 55 years. The yield of wild work on this. A few data on yields are found in non-refereed literature. The reported harvest yields span from 0.1 to 10 tones of seed/ha.

A few yield determining parameters are discussed in table 1 including especially, the planting density, which varies in this example between 625-2500 plants per ha. Plant density between $830(3 \times 4 \mathrm{~m})$ and $1111(3 \times 3 \mathrm{~m})$ are mostly chosen. It can be derived, that with the lowest planting density, between $6.4-25.6 \mathrm{~kg}$ of seed per plant have to be harvested if oil yields ranging between 1 and 4 tones per ha are expected. If pressing is done physically (screw pres) the press residue still contains between 6-9\% of rest oil. If solvent extraction is used it lies below $1 \%$, which means that the latter procedures achieves an oil yield that is about $20 \%$ higher. Production and harvest details of the most important oil crops are given in table 2 .

\section{Oil quality}

Jatropha oil very much mirrors rape seed fatty acid composition (table 3) and in important physical parameters (table 4). Hence it is well suited for conversion into biodiesel. Within the scope of a research project with DaimlerChrysler and the CSMCRI, Bhavnagar, India, parameters were developed for a high value biodiesel from Jatropha oil. First street tests with common rail injection (CDI) diesel cars and lately small transporters (track cars) started as early as 2004. To date, approximately 100.000 L of neat Jatropha biodiesel (Jatropha methyl ester, JME) have been tested under various climatical conditions. These tests have shown that there is only a minimally better efficiency of $1.7 \%$ in consumption in favour of fossil diesel (table 5), whereas the particulate matter dropped by $80 \%$ in JME.

JME meets EN specification 14214. Further information on biological properties can be found in [16].

\section{Competition between food and fuel production}

In the year 2007 cereal trade amounted to close to 250 million tones globally. The main imports of cereal went to Asia with 108 million tones, followed by Africa with 49 million tones. Based on average yields of 5 tones of cereal (Asia) and 0.5 tones for Africa, an area of 21 million and 98 million respectively would be necessary to produce those imports. There is no doubt that those areas are available without problems if the production is profitable for the small scale farmers. But there is a need for micro fertilization of food crops all over the lesser developed countries. Examples from the Sahelian countries are very promising concerning 
Table 1. Potential yield of Jatropha curcas L. plantations (mechanical oil pressing, $35 \%$ oil seed content, $7 \%$ rest oil in press cake).

\begin{tabular}{|c|c|c|c|}
\hline \multirow[t]{2}{*}{ Tons oil/ha } & \multicolumn{3}{|c|}{ Needed output with various planting densities (kg seeds/plant) to achieve the targeted oil yield } \\
\hline & $\begin{array}{l}4 \mathrm{~m} \times 4 \mathrm{~m} \\
(625 \text { plants } / \text { ha) }\end{array}$ & $\begin{array}{l}2 \mathrm{~m} \times 4 \mathrm{~m} \\
(1,250 \text { plants } / \mathrm{ha})\end{array}$ & $\begin{array}{l}2 \mathrm{~m} \times 2 \mathrm{~m} \\
(2,500 \text { plants } / \mathrm{ha})\end{array}$ \\
\hline 4.0 & 25.6 & 12.8 & 6.4 \\
\hline 2.0 & 12.8 & 6.4 & 3.2 \\
\hline 1.5 & 9.6 & 4.8 & 2.4 \\
\hline 1.0 & 6.4 & 3.2 & 1.6 \\
\hline
\end{tabular}

Table 2. Production and harvest details of the most important oil producing plants.

\begin{tabular}{|c|c|c|c|c|}
\hline \multirow[t]{2}{*}{ Oil plant } & \multirow{2}{*}{$\begin{array}{l}\text { Worldwide* oil production } \\
\text { (Mill. tones) }\end{array}$} & \multicolumn{3}{|c|}{ Average harvest (tones $\mathrm{ha}^{-1} \mathrm{y}^{-1}$ ) } \\
\hline & & Fruits & Oil & Oil content $(\%)$ \\
\hline Oil palm & 33.2 & $17.8^{2}$ & 3.57 & 20.0 \\
\hline Soy bean & 32.4 & $2.28^{1}$ & 0.38 & 16.7 \\
\hline Canola & 15.7 & $1.54^{1}$ & 0.58 & 37.6 \\
\hline Sunflower & 9.2 & $1.17^{1}$ & 0.44 & 37.6 \\
\hline Groundnut & 4.9 & $1.42^{1}$ & 0.22 & 15.5 \\
\hline Cotton & 4.8 & $1.10^{1}$ & 0.12 & 16.7 \\
\hline Jatropha curcas & $<0.1$ & $<0.1-?$ & $?$ & $\begin{array}{l}\sim 35.0^{3} \\
<25-42\end{array}$ \\
\hline
\end{tabular}

*USDA, 2006. ${ }^{1}$ USDA, 2006 [8]. ${ }^{2}$ IFEU, 2006 [9]. ${ }^{3}$ Own data.

mineral fertilization. Here it could be shown, that $4 \mathrm{~kg}$ of pure phosphate per hectar of millet increased grain harvest by 100 and straw yield by $400 \%$ [17]. Still it must be emphazised that energy plants are not produced on potentially arable farm lands in countries with food deficits. Jatropha offers a solution because it thrives on degraded soils, even in the desert of Upper Egypt as long as the inputs, water and nutrients are made available.

Table 3. Fatty acid composition of toxic and non-toxic Jatropha curcas oil.

\begin{tabular}{|lc|}
\hline Systematic name & $\begin{array}{c}\text { Toxic } \\
\text { (\%) }\end{array}$ \\
\hline Myristic & 0.1 \\
Palmitic & 15.3 \\
Heptadecanoic & 0.1 \\
Stearic & 6.6 \\
Arachidic & 0.2 \\
Behenic & $\mathrm{tr}$ \\
Lignoceric & $\mathrm{tr}$ \\
Total saturated & 22.3 \\
Palmitoleic & 0.9 \\
Oleic & 41.0 \\
Eicosenoic & 0.1 \\
Total monosaturated & 42.0 \\
Linoleic & 35.3 \\
A-linoleic (ALA) & 0.3 \\
Total PUFA & 35.7 \\
\hline
\end{tabular}

\section{Social-economic impact of Jatropha cultivation}

Many of the 500-600 millions of small scale farmers in lesser developed countries cultivate 20$30 \%$ of their land with an extremely high production risk, because this portion of their land is heavily degraded. Bad harvests are the norm on such areas. Therefore, it is suggested to cultivate a perennial on such soils, like Jatropha. The very positive influence of this kind of vegetation will help reclaim this land in a relative short period of time and make it again suitable for staple crop production.

A positive influence is also to be expected with respect to labour engagement in the rural areas. We estimate that a year-round labour force of 30 for 100 ha is required if most of the work on the plantation is done by hand

Table 4. Typical physical and chemical properties of Jatropha curcas seed oil.

\begin{tabular}{|ll|}
\hline Calorific value & $\mathbf{3 7 . 8} \mathbf{~ M J / k g}$ \\
\hline Appearance & Light yellow liquid \\
Specific gravity at $30^{\circ} / 30^{\circ}$ & 0.92 \\
Acid value & 1.24 \\
Saponification value & 197 \\
lodine value & 102 \\
Unsaponifiable matter & $0.4 \%$ \\
\hline
\end{tabular}

Source: Cooperation project DaimlerChrysler, CSMCRI and Hohenheim labour. A bioenergy plant would also save hard currency for developing countries by reducing the import bill of fossil fuels.

Another negative effect results from climate change, especially the distribution and amount of precipitation. Subsistence oriented small scale farmers cultivate their land solely by hand labour, whereas semi-intensive farms resort to a certain mechanisation. This gives them a comparative advantage because they are able to prepare their fields to plant the seeds in the desired acrage with a higher power of impact if the rainfall comes very late. Farmers that solely rely on hand labour are unable to cultivate all their fields in the short period of remaining time. This could be improved by offering an affordable type of bio-fuel.

\section{Conclusion}

In contrast to other fossil fuel alternatives, like biofuels from food crops such as maize, soy bean, sugar cane and palm, bioenergy from Jatropha curcas grown on wasteland incurs no carbon debt and thus, offers immediate and sustained greenhouse gas advantages.

Converting crop or grasslands to expand biofuel production will probably worsen the $\mathrm{CO}_{2}$-emission and thus global warming. It would also threaten food security.

Jatropha curcas, a native perennial to tropical regions, is adapted to harsh environmental conditions. It's multifunctional properties and 
Table 5. Jatropha curcas - oil and biodiesel quality.

\begin{tabular}{|c|c|c|c|c|c|c|}
\hline & \multirow{3}{*}{ Units } & \multirow{3}{*}{ EU3 Limits } & \multicolumn{4}{|c|}{ Actual measurements } \\
\hline & & & \multirow[t]{2}{*}{ Fossil Diesel } & \multirow[t]{2}{*}{ Bio Diesel } & \multicolumn{2}{|c|}{ Changes against limits \% } \\
\hline & & & & & Fossil & Bio Diesel \\
\hline $\mathrm{CO}$ & $\mathrm{g} / \mathrm{km}$ & 0,64 & 0.08 & 0.11 & -88 & -83 \\
\hline $\mathrm{HC}$ & $\mathrm{g} / \mathrm{km}$ & 0.56 & 0.04 & 0.02 & -92.9 & -96.4 \\
\hline $\mathrm{NO}_{\mathrm{x}}$ & $\mathrm{g} / \mathrm{km}$ & 0.5 & 0.37 & 0.39 & -26 & -22 \\
\hline Particulates & $\mathrm{g} / \mathrm{km}$ & 0.05 & 0.03 & 0.01 & -40 & -80 \\
\hline Fuel consumption & $\mathrm{L} / 100 \mathrm{~km}$ & & 6.47 & 6.58 & & $1.70 \%$ \\
\hline
\end{tabular}

a potential array of uses give the plant advantages over other oil producing crops. Because of the toxic compound "phorbol ester" [18] the oil from the toxic genotype is not edible and hence does not compete with human consumption, as long as it is planted on degraded lands.

Due to the wild nature of the plant, productivity varies considerably. This huge variation is of importance from a breeder's point of view for future selection and breeding programs. Such programs coupled with the development of agronomical practices, are essential prerequisites for economic exploitation of Jatropha curcas.

\section{REFERENCES}

1. Energy Information Administration (EIA). Annual Energy Outlook 2006 - with projections to 2030. US Department of Energy, 2006.

2. Hallauer AR, Miranda JB. Quantitative genetics in maize breeding. Ames, IA (USA) : lowa State University Press, 1988.

3. Silveira $\mathrm{CC}$, da. Contribution à l'étude du Pulghére aux iles du Cap Vert. Anais do Instituto Superior de Agronomia (Lisboa) 1934; 6: 116-26.

4. Grillo F. Monteiro. Notas sobre a economia de Cabo Verde. Culturas industriais Cabo Verde Bol. De. Propaganda e Informacão 1951 ; 3 : 2-4.
5. Heller J. Physic Nut Jatropha curcas L., Promoting the conservation and use of underutilized and neglected crops. 1. Rome (Italy) : International Plant Genetics and Crop Plant Research, Gartersleben, International Plant Genetic Resources Institute, 1996.

6. Heller J. Untersuchungen über genotypische Eigenschaften und Vermehrungs- und Anbauverfahren bei der Purgiernuß (Jatropha curcas L.). Hamburg (Germany) : Verlag Kovac, 1992.

7. Kolbike H. Untersuchungen zur Bestandsbegrünung von Purgiernuß (Jatropha curcas L.), Diploma (M.Sc.) Thesis, University of Hohenheim, Stuttgart (Germany), 1989.

8. Becker K, Makkar HPS. Jatropha curcas seed meal: A potential protein supplement for livestock feeds. Book of Abstracts, 1A5. 1996. All African Conference on Animal Agriculture. Oral presentation,

9. Richter N, Francis G, Becker K. Differential treatment of non-toxic Jatropha curcas $L$. and its impact on growth performance and whole body mineral absorption of common carp, Cyprinus carpio L. Book of Abstracts, 242. Deutscher Tropentag "The Global Food and Product Chain -Dynamics, Innovations, Conflicts, Strategies". 2005; poster.

10. Becker K, Makkar HPS. Effects of phorbolesters in carp (Cyprinus carpio L.). Veterinary and Human Toxicology 1998 ; 40 : 82-6.

11. Makkar HPS, Becker K. Nutritional studies on rats and fish (carp Cyprinus carpio) fed diets containing unheated and heated Jatropha curcas meal of a non-toxic provenance. Plant Foods for Human Nutrition $1999 ; 53$ : 182-92.
12. Kumar V, Makkar HPS, Becker K. Detoxification of Jatropha curcas seed meal and its utilization as a protein source in fish diet. Comparative Biochemistry and Physiology - A: Comparative Physiology 2008; 151: 13-14. 2008. 25th ESCPB Congress. oral

13. Makkar HPS, Becker K. Challenges and opportunities for using byproducts from the production of biodiesel from Jatropha oil as livestock feed. In : Pattanaik AK, Verma AK, Kamra DN, Sharma K. Proceedings 1, 168-170. 2009. Delhi, India, Animal Nutrition Association. Animal Nutrition World Conference 2009. oral

14. Goel G, Makkar HPS, Francis G, Becker K. Phorbol esters: Structure, biological activity and toxicity in animals. Int / Toxicol 2007; 26: 279-88.

15. Makkar HPS, Aderibigbe AO, Becker K. Comparative evaluation of a non-toxic and toxic variety of Jatropha curcas for chemical composition, digestibility, protein degradability and toxic factors. Food Chem $1998 ; 62$ : 207-15.

16. Makkar HPS, Becker K. Jatropha curcas, a promising crop for the generation of biodiesel and value-added coproducts. Eur / Lipid Sci Technol 2009 in press.

17. Buerkert A. Effects of crop residues, phosphorus and spatial soil variability on yield and nutrient uptake of pearl millet (Pennisetum glaucum L.) in Southwest Niger. Stuttgart, Germany : Verlag Ulrich Grauer, 1995.

18. Goel G, Makkar HPS, Francis G, Becker K. Phorbol esters: Structure, biological activity, and toxicity in animals. Int / Toxicol 2007; 26 : 279-88. 